\title{
ANalysis of Well Field Nitrates Pollution Distribution in Agricultural AREA
}

\author{
Lado Kranjčević, Marko Šrajbek, Luka Grbčić \& Zoran Čarija
}
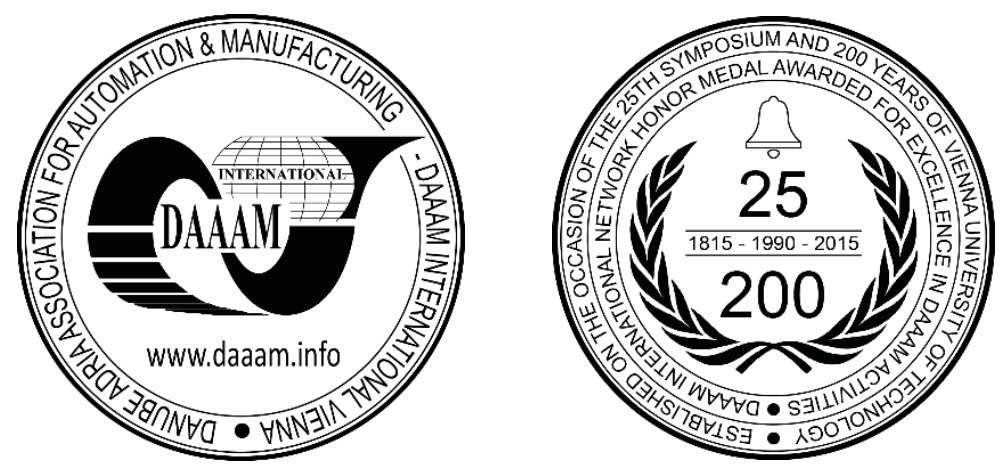

This Publication has to be referred as: Kranjcevic, L[ado]; Srajbek, M[arko]; Grbcic, L[uka] \& Carija, Z[oran] (2018). Analysis of Well Field Nitrates Pollution Distribution in Agricultural Area, Proceedings of the 29th DAAAM International Symposium, pp.1053-1058, B. Katalinic (Ed.), Published by DAAAM International, ISBN 978-3-90273420-4, ISSN 1726-9679, Vienna, Austria

DOI: $10.2507 / 29$ th.daaam.proceedings. 150

\begin{abstract}
A study of groundwater quality at a particular well field near Varaždin, the north-western part of Croatia is presented in this paper. Experimental date are collected for the period of 11 years and nitrate concentration annual average for each well and piezometer are calculated. The Varaždin well field is out of production for decades because of the high nitrate pollution levels in groundwater. The well field is surrounded by agricultural fields and urban area. In order to determine a spatial nitrate concentration change, eight arbitrary starting points are set and distance to each of the wells is determined. Eight directions of the nitrate pollution gradient are analysed and principal direction is detected pointing to the area where probable pollution source is to be found. The results show a decrease in nitrate concentration in the southwest - east direction at the wellfield area. The principal nitrate concentration gradient is compared to the groundwater flow direction in the area. The possible area of continuous contamination, possibly by agricultural reasons is determined as a first step to remedy this public health problem of the highest priority.
\end{abstract}

Keywords: groundwater; nitrates pollution; agricultural pollution; pollution source detection

\section{Introduction}

Water is one of the most abundant substances on Earth and necessary for the entire living world. When rainwater reaches the surface of the land, it dissolves many of the substances found there. No matter what kind of substrate is flowing, it comes to the underground and stays there. Such water is called groundwater and it is the main source of water for different human needs.

Today, there is an increasing interest and need for pure water, but at the same time, due to the increasingly intensive industrial and agricultural development and the impact of urban areas on the environment, degradation of groundwater quality is almost unavoidable. Changming et al. [1] showed that the growing water needs caused by urban and industrial development and the increase of irrigated agricultural areas lead to over-exploitation of groundwater which lead to degradation of groundwater. Also, some experiences show that application of fertiliser and pesticides in agriculture significantly degrades the quality of groundwater [2], [3], [4]. In this sense, groundwater of the Varaždin area is no exception. 
Therefore, taking into account the density of the city of Varaždin population and the intensity of its development, groundwater protection should be one of the main preconditions for further development of the region and the quality of life improvement. Groundwater of the Varaždin area has been polluted for a long time showing high levels of the nitrate concentration [5] which was higher than maximum allowable concentration by MAC [6], [7], [8]. The problem was solved by increasing the pumping rate at the wellfields where the nitrate concentration was under MAC [9].

In order to protect the quality of groundwater, primarily in terms of nitrate concentration, the aim of this paper is to determine the direction of the growth of nitrate concentrations at the micro location of the Varaždin wellfield. The results can serve as a basis for further research, such as location and quantification of pollutant sources. After the pollution sources localisation, a number of necessary operational steps should be taken on the ground [10] in order to remedy this high priority problem.

\section{Materials and methods}

The city of Varaždin is located in the north-west part of the Republic of Croatia, on the right bank of the river Drava, $70 \mathrm{~km}$ away from the capital city of Zagreb. It is a cultural, social and educational center of the Varaždin County. Along the eastern part of the town a wellfield Varaždin is placed (Figure 1), in a lowland catchment and draw groundwater from the alluvial aquifer built of quaternary sand and gravel. The aquifer system is divided by a semipermeable layer of clay and silt in upper and lower aquifer [11]. The analyses carried out in this paper relate only to the upper aquifer in the period from 1993 to 2003, when the wellfield was in operational conditions.

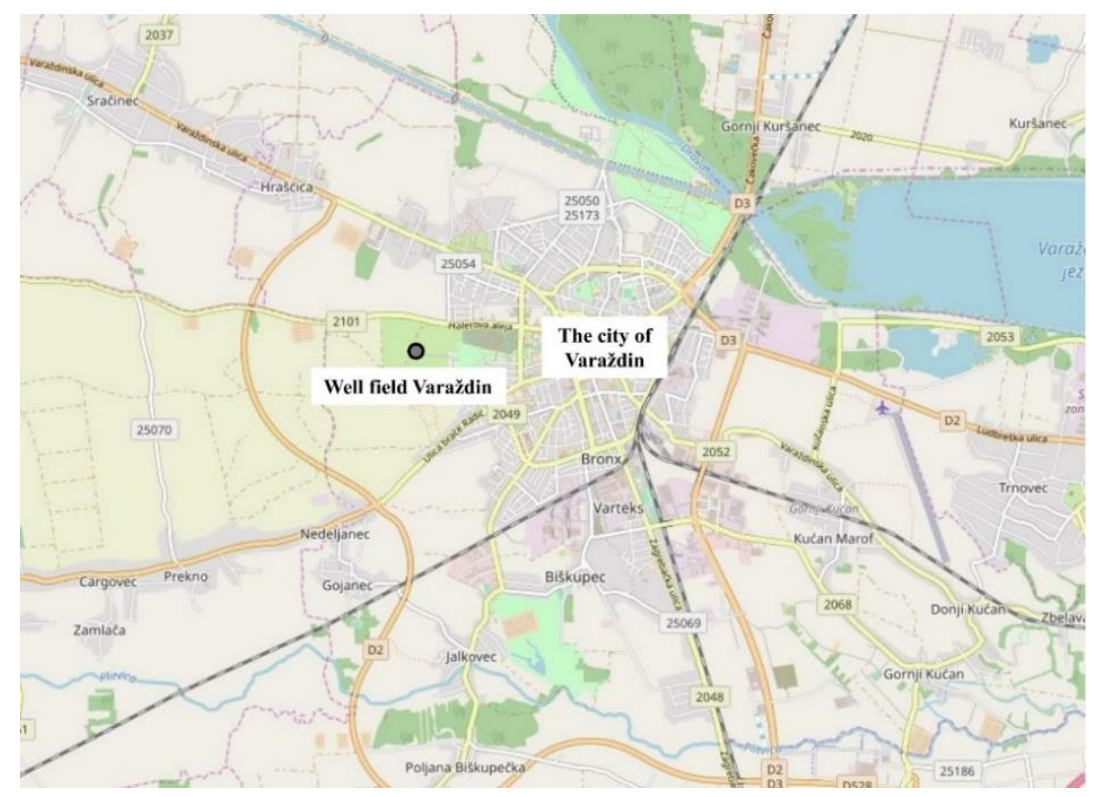

Fig. 1. Location of the Varaždin well field

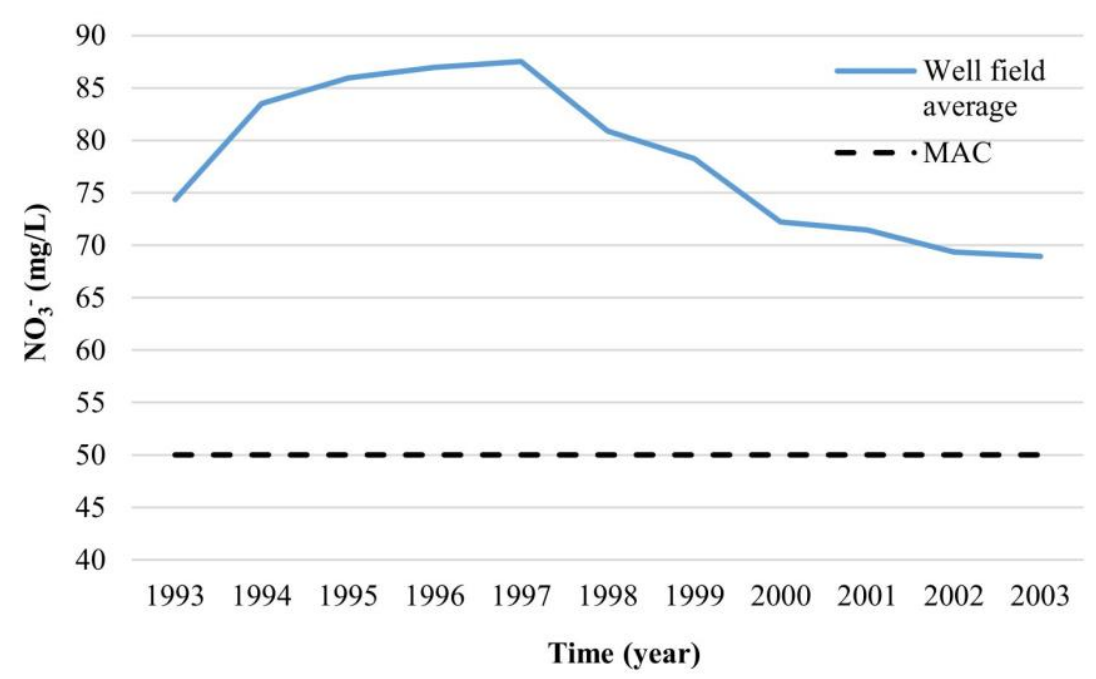

Fig. 2. Nitrate concentration annual averages in the observed period and referent MAC value 
Groundwater in the observed period at the Varaždin wellfield was of a good quality, except for the high nitrate concentration values. Values of this parameter were constantly above MAC recommended levels (Figure 2). As seen in Fig. 2, the nitrate concentration annual averages are ranging from 70 to $90 \mathrm{mg} / \mathrm{L} \mathrm{NO} 3-$. Because of this reason, the wellfield has been inactive since 2004. Today, this location is used only in time of highest water demands.

In order to determine the direction of the of nitrate concentration spread on the micro location of the Varaždin wellfield, the starting points labelled from 1 to 8 were defined (Figure 3). The distances to wells and piezometers were measured from each starting point to the well locations (B3 to B10 and probe wells P23, P25, P26, P29 and P30 (Table 1).

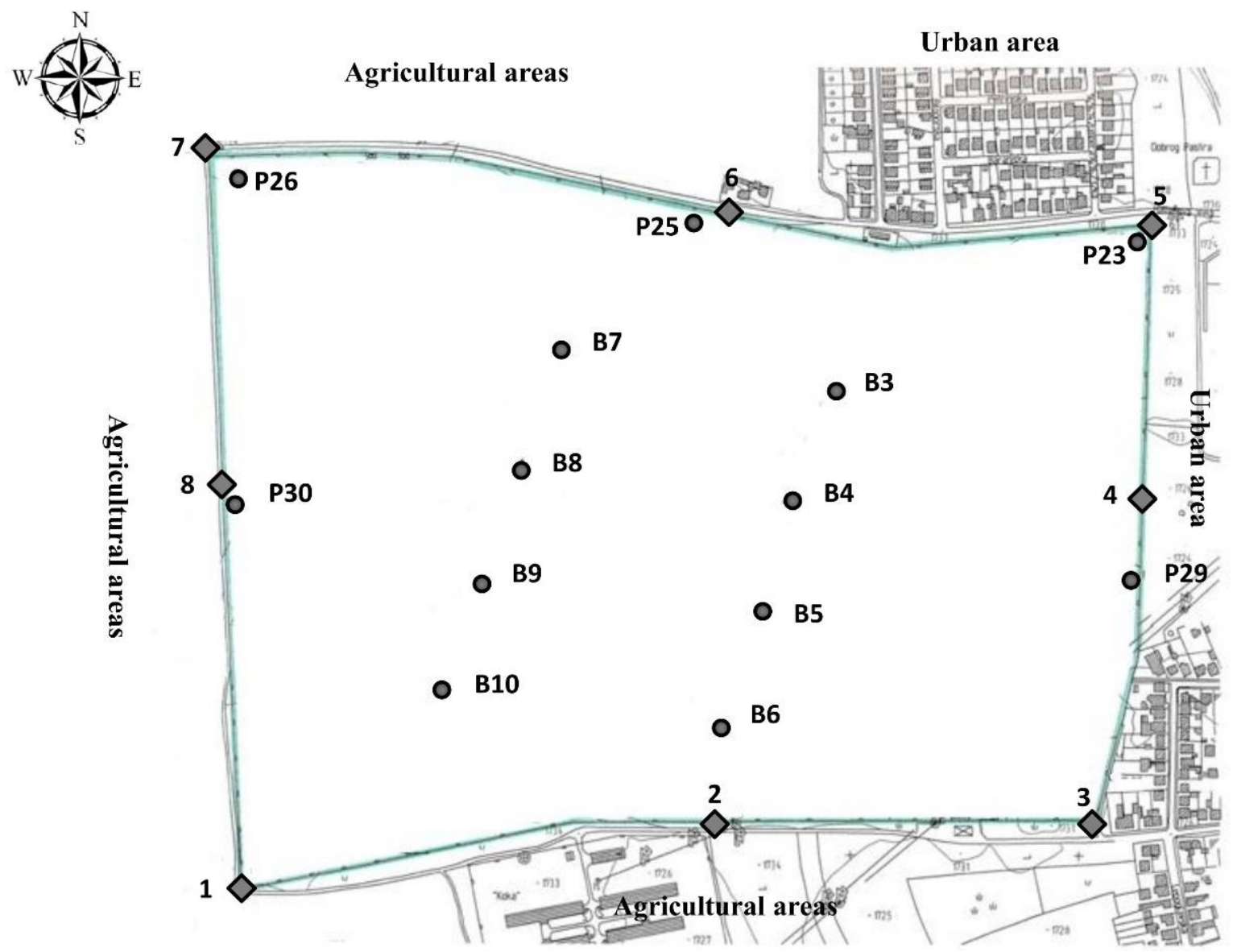

Fig. 3. Spatial distribution of wells, piezometers and starting points in the well field Varaždin

\begin{tabular}{cccccccccc}
\hline Well/piezometar & & \multicolumn{9}{c}{ Distances (m) } & & & \multicolumn{2}{c}{$\begin{array}{c}\mathbf{N O}^{-} \\
(\mathbf{m g} / \mathbf{L})\end{array}$} \\
& $\mathbf{1}$ & $\mathbf{2}$ & $\mathbf{3}$ & $\mathbf{4}$ & $\mathbf{5}$ & $\mathbf{6}$ & $\mathbf{7}$ & $\mathbf{8}$ & \\
\hline B3 & 860 & 521 & 564 & 380 & 384 & 268 & 745 & 700 & 72,78 \\
B4 & 747 & 392 & 495 & 379 & 495 & 346 & 743 & 636 & 75,66 \\
B5 & 635 & 249 & 442 & 415 & 609 & 462 & 790 & 605 & 77,73 \\
B6 & 578 & 146 & 418 & 468 & 714 & 583 & 862 & 617 & 81,41 \\
B7 & 693 & 540 & 794 & 672 & 648 & 218 & 447 & 426 & 75,89 \\
B8 & 559 & 434 & 751 & 677 & 735 & 351 & 489 & 340 & 81,39 \\
B9 & 437 & 345 & 728 & 710 & 822 & 478 & 562 & 307 & 85,88 \\
B10 & 318 & 293 & 733 & 774 & 932 & 608 & 638 & 318 & 84,06 \\
P23 & 1210 & 828 & 658 & 376 & 27 & 464 & 1000 & 1030 & 67,97 \\
P25 & 885 & 671 & 808 & 624 & 500 & 21 & 537 & 609 & 74,16 \\
P26 & 786 & 873 & 1210 & 1090 & 1010 & 519 & 16 & 372 & 67,15 \\
P29 & 1020 & 573 & 301 & 30 & 389 & 623 & 1100 & 984 & 62,19 \\
P30 & 414 & 582 & 1010 & 987 & 1040 & 610 & 386 & 15 & 79,19 \\
\hline
\end{tabular}

Table 1. Distances from starting points to wells and piezometers and nitrate concentrations 
Based on the nitrate concentration annual averages (Table 1, Figure 2) and the distances of each starting point to the wells and the probe wells (Table 1), a total of 8 scatter diagrams were created (Figure 4).
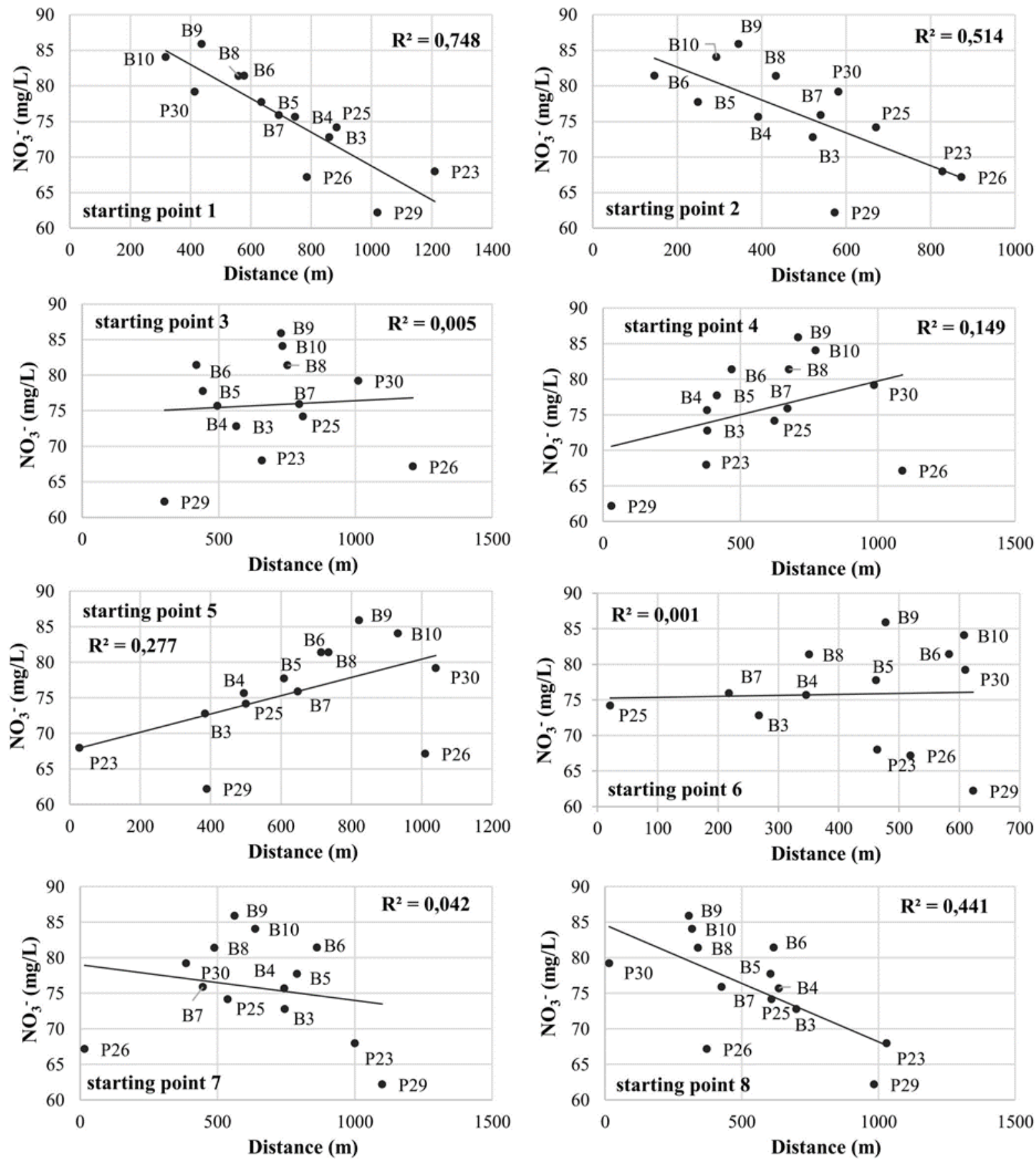

Fig. 4. Scatter diagrams: distance - nitrate concentration for the starting points 1 to 8

Each diagram contains 13 different pairs of data: distance - nitrate concentration. In the experimental data, presented in the scatter diagrams, regression lines were fitted. Coefficients of determination are calculated according to the following equations:

$$
\begin{aligned}
& R^{2}=1-\frac{S S_{\text {res }}}{S S_{\text {tot }}} \\
& S S_{\text {res }}=\sum_{i}\left(c_{i}-f_{i}\right)^{2}
\end{aligned}
$$




$$
S S_{t o t}=\sum_{i}\left(c_{i}-\bar{c}\right)^{2}
$$

where $\mathrm{R}^{2}$ is a coefficient of determination, $\mathrm{SS}_{\text {res }}$ is the residual sum of squares, $\mathrm{SS}_{\text {tot }}$ is the total sum of squares, $\mathrm{c}_{\mathrm{i}}$ are the nitrate concentration annual averages, $\bar{c}$ is the nitrate concentration average field and $f_{i}$ are the modelled nitrate concentration annual averages. The reliability of the model was determined by the t-test according to the following equation:

$$
t=r \sqrt{\frac{d f}{1-r^{2}}}
$$

where $r$ is a correlation coefficient and $d f$ represents the degree of freedom:

$$
d f=N-2=11 \text {. }
$$

The obtained $t$ values were compared to the critical $\mathrm{t}$ value $\left(\mathrm{t}_{\alpha}\right)$ for the signification level of $5 \%, t_{\alpha}=2,201$. A model is reliable if the following condition is fulfilled:

$$
t>t_{\alpha}
$$

\section{Results and discussion}

The Fig. 4. shows the arbitrary positions of starting points $1-8$ (diamond signs in Fig. 3) and indicates the nitrates concentration drop in eight different directions. Even the first look at the scatter diagrams reveals the dominant direction being the direction across the starting point 1 followed by directions through points 2 and 8 . The three principal directions are confirmed in Table 1 by their coefficients of determination $R^{2}$ and referent $t$ values (equations $1-6$ ).

\begin{tabular}{ccc}
\hline Starting point & $\mathbf{R}^{\mathbf{2}}$ & t value \\
\hline 1 & 0,748 & 5,715 \\
2 & 0,514 & 3,411 \\
3 & 0,005 & 0,233 \\
4 & 0,149 & 1,388 \\
5 & 0,277 & 2,052 \\
6 & 0,001 & 0,103 \\
7 & 0,042 & 0,695 \\
8 & 0,441 & 2,945 \\
\hline & & $\mathrm{t}_{\alpha}=2,201$
\end{tabular}

Table 2. Reliability values

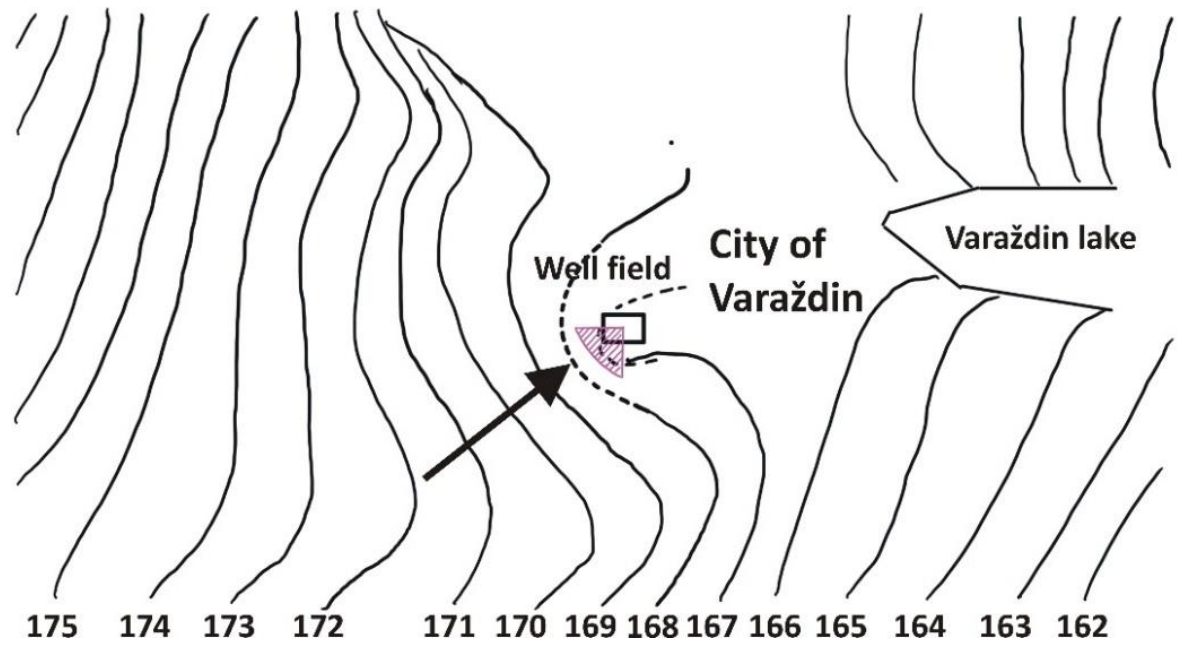

Fig. 5. Groundwater level chart in Varaždin area in 1985. and mayor groundwater flow direction in the greater Varaždin area [12] 
Every directions could be visualised in Fig. 4 as a line passing through one of the starting points and the imaginary point in the geometrical center of the Varaždin well field. Therefore, the dominant direction through starting point 1 spreads from the well field center to the south-west while the second in magnitude, direction through the starting point 2 spreads toward the west and the third direction in magnitude points south.

The three dominant directions form a fan, shown in Fig. 5, spreading from the Varaždin well field to the south-west. The Varaždin well field has been out of the production for decades, because of its high nitrogen pollution levels. The most probable position of the contamination source should therefore be located somewhere in the indicated fan area. It is still not clear whether it is a point source or non-point source pollution type of contaminant. It is surely of the agricultural origin but the exact point should be sought after and located. The reverse engineering method assuming nitrogen spread by diffusion, should be employed to track back to the pollution source or sources (as in [13]).

At the same time, the other indicative direction is the direction of the groundwater flow, as being depicted by arrow in Fig. 5. The groundwater flow direction follows the drop in the ground water levels, and in the vicinity of the city of Varaždin it is clearly the south-west to north-east direction, the same direction as the nitrogen pollution gradient direction found earlier in this text. It is to be cleared whether these two directions coincide by chance or, or there is some correlation between them.

\section{Conclusion}

The many decades long high nitrogen pollution levels in the precious Varaždin well field area represent the public health problem of the highest priority because it involves the most important human asset - the drinking water. The Varaždin well field has been showing the nitrate concentration levels higher than the maximum allowable values by MAC as shown in Fig. 2. In this paper we explained the gravity of the situation in the mentioned area and we set ground for further necessary scientific investigation steps by detecting the primary direction in which the nitrate pollution spreads to be south-west to north-east direction. Analysing the records of the Varaždin aquifer area we also found that the groundwater flow also spreads in the same direction and further investigation should answer the question what is the correlation between the nitrogen gradient drop and the groundwater flow directions. In order to locate the exact pollution source (or sources) location, further investigation should employ the reverse engineering method, while the principal search area is already clearly shown in this paper.

\section{References}

[1] Changming, L.; Jingjie, Y.; Kendy, E. (2010). Groundwater exploitation and its impact on the environment in the North China Plain. Water International, 26(2), 265-272.

[2] Almasri, M. N., \& Kaluarachchi, J. J. (2005). Modular neural network to predict the nitrate distribution in ground water using the on ground nitrogen loading and recharge data. Environmental Modelling and Software, 20(7), 851871.

[3] Mao, X.; Prommer, H.; Barry, D. A.; Langevin, C. D.; Panteleit, B.; Li, L. (2006). Three-dimensional model for multi-component reactive transport with variable density groundwater flow. Environmental Modelling and Software, 21(5), 615-628.

[4] McLay, C. D.A.; Dragten, R.; Sparling, G.; \& Sevarajah, N. (2001). Predicting groundwater nitrate concentrations in a region of mixed agricultural land use: a comparison of three approaches. Environmental Pollution, 115(2), 191204.

[5] Kovač, I. (2000). Analiza promjena zastupljenosti zagađivala u podzemnim vodama varaždinskog područja. Croatian geotechnical journal, 8, 15-16.

[6] European Union (EU) Council Directive 98/83/EC of 3 November 1998 on the quality of water intended for human consumption. Official Journal L 330, 05/12/1998 P.0032 - 0054.

[7] Commission Directive (EU) 2015/1787 of 6th of October 2015 amending Annexes II and III to Council Directive 98/83/EC on the quality of water intended for human consumption.

[8] Republic of Croatia, Ministry of Health (2017). Ordinance on conformity parameters and analysis methods, monitoring and water safety plans for human consumption. Official gazette 125/2017.

[9] Novotni-Horčička, N.; Šrajbek, M.; Kovač, I. (2010). Nitrati u Regionalnom vodovodu Varaždin. Voda i javna vodoopskrba Baška. Hrvatski zavod za javno zdravstvo, 123-131.

[10] Rusko, M., Kralikova, R., \& Mikulova, M. (2016). The management tools and methods application of the organization to environmental protection. Annals of DAAAM \& Proceedings, 27.

[11] Urumović, K. (1991). O kvartnom vodonosnom kompleksu na području Varaždina. Zagreb: Geološki vjesnik, 24.

[12] Urumović, K.; Hlevnjak, B.; Prelogović, E.; Mayer,D. (1990). Hidrogeološki uvjeti Varaždinskog vodonosnika, Geološki vjesnik br. 43, Zagreb.

[13] Kranjčević, L, Čavrak, M., Šestan, M., (2010). Contamination source detection in water distribution networks, Engineering Review, 30, 2, 11-25, 2010. 